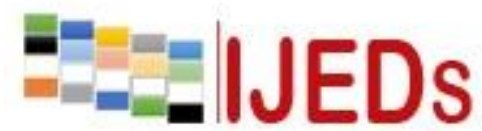

http://ijeds.ppj.unp.ac.id/index.php/IJEDS

\title{
THE EFFECT OF PROBLEM SOLVING METHOD ON MOTIVATION AND LEARNING MATHEMATIC RESULTS OF CLASS V SDN 29 SAOK LAWEH KABUPATEN SOLOK
}

\author{
${ }^{*}$ Trisno $^{1}$, Risda Amini ${ }^{1}$ and Irdamurni ${ }^{2}$ \\ ${ }^{1}$ Primary Education Student, Edcuation Study, Pascasarjana, \\ Universitas Negeri Padang \\ ${ }^{2}$ Instructor Staff Primary Edcuation Study, Pascasarjana, Universitas Negeri Padang \\ Email: trisno_malinkayo@yahoo.co.id
}

*Corresponding Author, Received: November 12, 2018, Revised: December 10, 2018, Accepted: December 21, 2018

\begin{abstract}
The learning process in the classroom is still dominated by conventional teaching, teachers was seldom to invite and provide opportunities for students to interact, collaborating or cooperating with their classmates. This problem like this can give an impression to students that math lessons are boring and scary. The purpose of this research is to get information about the effect of student learning outcomes who teach by using problem solving methods with the motivation of students who teach by using conventional methods in learning mathematics in class V SDN 29 Saok Laweh Kabupaten Solok. The design of the research is quasy experiment. The population is all fifth grade students that consist of 2 classes with 48 people. Sampling was gathered by random sampling technique. The research data was collected using the initial ability test and final ability test. The results of the research that found the learning outcomes of students who teach by using problem solving methods had better that students' learning motivation learning outcomes who teach by using conventional methods with a $t_{\text {count }}$ is 1.984 greater than $t_{\text {table }}$ that found 4.72 with a real level of $\alpha=0.05$. Calculation results in the table using the $F_{\text {test }}$ can found $F_{\text {count }}$ are 4.258. Furthermore, $F_{\text {table }}$ is found 4.11. It can be concluded that there are differences in students' learning outcomes who teach by using problem solving methods with students' learning outcomes who teach by using conventional methods. It means that there are differences in motivation of students teach using problem solving methods with motivation of students who teach by using conventional methods in learning mathematics in Class V SD Negeri 29 Saok Laweh Kecamatan Kubung.
\end{abstract}

Keywords: Problem Solving, Motivation and Learning Outcomes

\section{INTRODUCTION}

Education is a process and outcome. As a process, education is a series of systematic activities that are directed towards changes in student behavior that are 


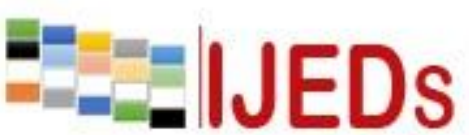

http://ijeds.ppj.unp.ac.id/index.php/IJEDS
International Journal of Educational Dynamics

Vol. 1 No. 1 (pp. 303-308) December 2018

p_ISSN 2655-4852

e_ISSN 2655-5093

reflected in knowledge, attitudes and behavior within the family, school and society (Hermon and Dalim, 2005). Education does not only intellectuality, but also emphasizes the process of developing students' personalities as a whole so that children become more mature (Hermon, 2015). The active classroom situation and high motivation to learn mathematics and also follow by mathematics learning outcomes above the KKM set by the school are ideal conditions expected by each teacher. But often the facts that occur are not in line with expectations. Reality in the field proves that in some schools still applying teacher center learning methods (teacher-centered learning). That conditions was happened in SD Gugus VII Kecamatan Kubung, Kabupaten Solok, which causes the results obtained by students in learning to be still low because there are still many students who are below the Kriteria Ketuntasan Minimal (KKM) that have been set. The teacher just explained learning material without relationships between teachers and students, so students are not able to develop their thinking skills. It also encourages a sense of anxiety and fear in students. Anxiety is one of the psychological factors of students that determines the success of students in conducting the learning process in addition to several other factors, there are intelligence, talent, motivation, feelings, attitudes and interests. The existence of students 'anxiety factors raises students' dislike with mathematics, so they are lacking in enthusiasm and passionate to attending mathematics lessons which have an impact on the low learning outcomes achieved by students. This will not be able to improve human resources. Another thing that causes low mathematics learning outcomes are observed in the learning process in the classroom, namely the existence of internal factors (in students) and external factors (outside of students).

To solve this problem so that it is not sustainable it is necessary to apply the right learning method, so that it can increase motivation and student learning outcomes in learning mathematics. One of the learning methods that can be applied is problem solving learning methods (Hermon, 2014). Problem solving learning method is a learning method that focus on problem solving skills. When faced with a question situation, students can perform problem solving skills to choose and develop their responses. Not only by memorizing without thinking, problem solving skills expand the thought process. It allows students to be able to store essential concepts given in long- 


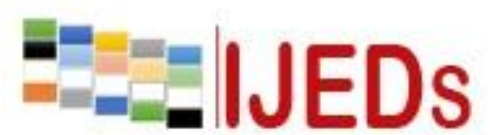

http://ijeds.ppj.unp.ac.id/index.php/IJEDS
International Journal of Educational Dynamics

Vol. 1 No. 1 (pp. 303-308) December 2018

p_ISSN 2655-4852

e_ISSN 2655-5093

term memory (long term memory) and allow them to use concepts when thinking at a higher level (higher level of thinking).

Based on the description above, researchers want to try to see the extent of the influence of increasing motivation and learning outcomes of mathematics by using problem solving methods. Problem solving method is a learning method that is able to improve students' ability to think highly (Suyitno, 2004). This happens because the problem solving method provides the widest opportunity for students to solve problems with their own strategies. According to Cahyono (2009), problem solving learning method is a learning that concentrates on teaching and problem solving skills, followed by strengthening skills. When faced with a question / problem, students can do problem solving skills to choose and develop their responses. Not only by memorizing without thinking, problem solving skills expand the thought process (Muslich, 2007). Selecting the right method, teachers are required to follow technological developments, especially information and communication technology (TIK) which has developed very rapidly in recent years.

\section{METHOD}

This research is using quantitative methods in the form of Quasi Experiment Design. There are two sample groups in this study, namely the experimental group that carried out learning with problem solving methods and control groups with conventional learning. This study uses two classes, namely the experimental class and the control class. The independent variable is the use of problem solving methods with conventional learning, the dependent variable is activity and learning outcomes, and this design is chosen because it is not possible to control the research variables in full. The population in this study were all Class V students of SD Negeri 29 Saok Laweh, Kecamatan Kubung who had a parallel class of 2017/2018 Academic Year, with the research sample being class $\mathrm{V}$ A as the experimental class and class $\mathrm{V}$ B as the control class. 


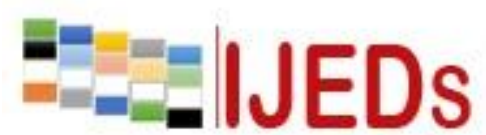

http://ijeds.ppj.unp.ac.id/index.php/IJEDS
International Journal of Educational Dynamics

Vol. 1 No. 1 (pp. 303-308) December 2018

p_ISSN 2655-4852

e_ISSN 2655-5093

\section{RESULTS AND DISCUSSION}

The results of the performance test data calculate the FPB and KPK per indicator in the experimental and control classes, so that the average value obtained in the experimental class is higher than the test results showing the students' motivation in the control class. The percentage of students' learning motivation obtained in the experimental class was 83.32 while the percentage of student learning motivation obtained in the control class was 57.68 .

Based on the calculation of hypothesis 1 that has been done, the results of testing hypothesis 1 can be seen from the calculation results using the $t$ test obtained by the combined variance of the two samples is 5.27 for the real level $\alpha=0.05 \mathrm{dk} 46$, so that the resulting $\mathrm{t}_{\text {count }}$ is 8.047 . While the table obtained is 1.68 . Because $t_{\text {count }}$ is greater

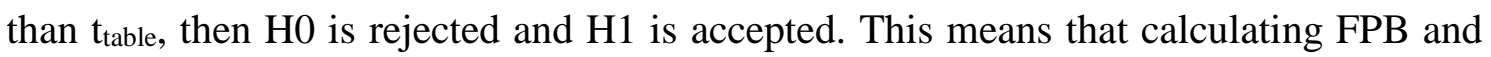
KPK students who learn to use problem solving methods is better than counting FPB and KPK students who learn using conventional methods.

The results of testing hypothesis 2 by using the $t$ test obtained by the combined variance of the two samples is 3.06 for the real level $\alpha=0.05 \mathrm{dk} 25$, so that the resulting $t_{\text {count }}$ is 12.789 . While the table obtained is 1.72 . Because $t_{\text {count }}$ is greater than table, then $\mathrm{HO}$ is rejected and $\mathrm{H} 1$ is accepted. This means that calculating FPB and KPK students who have high ability with learning using problem solving methods is higher than counting FPB and KPK students who have high abilities who learn using conventional methods.

The results of testing hypothesis 3 by using the $t$ test obtained by the combined variance of the two samples is 10.65 for the real level $\alpha=0.05 \mathrm{dk} 23$, so that the resulting $t_{\text {count }}$ is 1.984 . While the table obtained is 1.72 . Because $t_{\text {count }}$ is greater than $t$ table, then $\mathrm{H} 0$ is rejected and $\mathrm{H} 1$ is accepted. This means that calculating FPB and KPK students who have low ability with learning using problem solving methods is higher than calculating FPB and KPK students who have low abilities who learn using conventional methods.

Based on the results of the research that the author did in Class V of SD Negeri 29 Saok Laweh, Kecamatan Kubung, it was proven. motivation and learning outcomes of mathematics obtained from both sample classes, it can be seen that there 


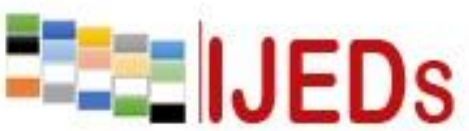

http://ijeds.ppj.unp.ac.id/index.php/IJEDS
International Journal of Educational Dynamics

Vol. 1 No. 1 (pp. 303-308) December 2018

p_ISSN 2655-4852

e_ISSN 2655-5093

are differences in motivation of students in the experimental class who are teach using problem solving methods with the motivation of students in the control class who are teach using conventional methods. Learning outcomes of students teach using problem solving methods are better than learning outcomes of students who are teach using conventional methods. The following will explain the picture of learning in the experimental class which is teach using problem solving methods and descriptions of learning in the control class teach using conventional methods

\section{CONCLUSION}

The results of data analysis and discussion of research data that has been done, it can be concluded that the problem solving method affects the calculation of FPB and KPK. There are differences in motivation of students' who teach by using problem solving methods with the motivation of students who teach by using conventional methods in mathematics learning in class V of SD Negeri 29 Saok Laweh, Kecamatan Kubung. Thus problem solving methods can increase student motivation. There are differences in learning outcomes of students who teach by using the problem solving method with learning outcomes of students who teach by using conventional methods in mathematics learning in class V of SD Negeri 29 Saok Laweh, Kecamatan Kecamatan Kubung. Learning outcomes of students who are teach using problem solving methods are better than learning outcomes of students' who teach by using conventional methods in mathematics learning in class V of SD Negeri 29 Saok Laweh, Kecamatan Kubung.

\section{REFERENCES}

Abimanyu, Soli. 2008. Strategi Pembelajaran. Jakarta: Direktorat Jendral. Pendidikan Tinggi, Departemen Pendidikan Nasional.

A.M. Sardiman. 2001. Interaksi dan Motivasi Belajar Mengajar. Jakarta: PT Raja Grafindo

Allen, K.Eillen. 2008. Profil Perkembangan Anak. Jakarta: Indeks.

Arikunto, Suharsimi. 2010. Prosedur Penelitian: Suatu Pendekatan Praktek. Jakarta: Rineka Cipta.

Arikunto, Suharsimi. 2008. Dasar-dasar Evaluasi Pendidikan. Jakarta: Bumi Aksara. BSNP. 2006. Standar Isi untuk Satuan Pendidikan Dasar dan Menengah. Jakarta: BSNP Dimyati dan Mudjiono. 2010. Belajar dan Pembelajaran. Jakarta: Rineka Cipta 
http://ijeds.ppj.unp.ac.id/index.php/IJEDS

Depdiknas. 2006. Panduan Penyusunan Kurikulum Tingkat Satuan Pendidikan. Jakarta: Depdiknas.

Desmita. 2007. Psikologi Perkembangan. Bandung: Remaja Rosdakarya.

Djajadisastra, Jusuf. 1981. Metode-metode Mengajar. Bandung: Angkasa

Djamarah dan Azwan Zain. 2006. Strategi belajar mengajar. Jakarta: PT. Rineka Cipta

Erman, Suherman, dkk. 2003. Strategi Pembelajaran Matematika Kontemporer. Bandung: Universitas Pendidikan Indonesia.

Habsari. 2005. Bimbingan dan Konseling untuk Kelas XII. Jakarta: PT Grasindo.

Hamalik, Oemar. 2001. Pendidikan Guru berdasarkan Pendekatan Sistem. Bandung: PPS UPI.

Hamalik, Oemar. 2010. Kurikulum dan Pembelajaran. Jakarta: Bumi Aksara.

Hanafiah, Nanang \& Cucu Suhana. 2010. Konsep Strategi Pembelajaran. Bandung: Refika Aditama.

Hermon, D and Y. Dalim. 2005. Penggunaan Media Audio Visual untuk Meningkatkan Kreatifitas Belajar. Jurnal Pembelajaran 28 (3), 266-276.

Hermon, D. 2014. Desain Kebijakan Tanggap Darurat dan Pemulihan Bencana Letusan Gunung Sinabung. Seminar Nasional Geografi. Master Program of Geography Education, Universitas Negeri Padang.

Hermon, D. 2015. Arahan Kebijakan Keberlanjutan Pendidikan 10 Tahun Pasca Bencana Tsunami di Kabupaten Aceh Jaya Provinsi Aceh. Seminar Nasional Geografi. Master Program of Geography Education, Universitas Negeri Padang.

Perdana, Mayang Putri 2014. Pengaruh metode problem solving terhadap hasil belajar siswa kelasas VIII. MTs. Assyafi'iyah Gondang pada materi sudut pusat, panjang busur, dan luas juring dalam pemecahan masalah. IAIAN Tulung Agung: 2014. 